\title{
The importance of
}

\section{asymmetric autoregressive stochastic volatility models in financial markets}

\author{
García-Centeno, María-Carmen
}

- received: 2 August 2015

- ACCEPTED: 12 NOVEMBER 2015

\begin{abstract}
The leverage effect is one of the most relevant stylized facts to modelling time-varying financial volatility because the effect that negative returns has on volatility is different to that produced by positive returns. For this reason, this paper focuses on two goals: (i) to analyse the main stylized facts of volatility using 20 indexes from the most important stock markets in Asia, Europe, North America and South America in the sample period, namely between January 3, 2000 and February 4, 2014; and, (ii) to estimate conditional heteroskedasticity using the classic econometric models typically used for this purpose (AGARCH, GJR-GARCH, EGARCH, APARCH) along with the symmetric (ARSV) and asymmetric (TA-ARSV) stochastic volatility models, and then to compare their results to determine which model best explains the main stylized facts of financial returns. The results show, on the one hand, that financial returns have the same characteristic features, regardless of the particular stock market and, on the other hand, that the TA-ARSV is the best model to explain the stylized facts.
\end{abstract}

\section{Keywords:}

EGARCH, AGARCH, GJR-GARCH, APARCH, TA-ARSV, Stochastic volatility, stylized facts.

JEL classification:

C13, C58, D53, G15, G17. 


\title{
La importancia de los modelos de asimétricos autorregresivos de volatilidad estocástica en los mercados financieros
}

\author{
García-Centeno, María-Carmen
}

\section{Resumen}

El efecto leverage es uno de los hechos estilizados más relevantes para modelizar la volatilidad financiera a lo largo del tiempo, ya que el efecto que causan los rendimientos negativos en la volatilidad es diferente del causado por los rendimientos positivos. Por esta razón, este trabajo se centra en dos objetivos: (i) analizar los principales hechos estilizados de la volatilidad utilizando 20 índices procedentes de los principales mercados bursátiles de Asía, Europa, Norteamérica y Sudamérica, en el periodo muestral comprendido entre el 3 de enero de 2000 y el 4 de febrero de 2014; y (ii) estimar la heterocedasticidad condicional a través de los modelos econométricos tradicionalmente utilizados para este propósito (AGARCH, GJR-GARCH, EGARCH, APARCH) y también con el modelo simétrico (ARSV) y el asimétrico autorregresivo de volatilidad estocástica, con el fin de comparar los resultados para determinar cuál es el mejor modelo para explicar los principales hechos estilizados de las series de rendimientos financieros. Los resultados muestran, por un lado, que los rendimientos financieros tienen los mismos hechos estilizados, con independencia del mercado bursátil analizado, $y$, por otro, que el modelo TA-ARSV es el mejor modelo para explicar dichos hechos estilizados.

\section{Palabras clave:}

EGARCH, AGARCH, GJR-GARCH, APARCH, TA-ARSV, volatilidad estocástica, hechos estilizados. 


\section{Introduction}

Volatility is one of the most important variables in financial markets because it provides an important input for portfolio management, option pricing and market regulation. Volatility is also related to the risk in this type of markets and for this reason, investors need to have as much information as possible in order to make decisions that provide them with the best results, especially in the current fluctuating market.

However, volatility is one of the most controversial variables in the financial literature and for this reason an increasing number of volatility models have been developed since Engle first proposed the ARCH model in the early 80's. These models try to explain the dynamics of volatility and their stylized facts.

There are several studies related to the stylized facts of returns; Granger and Ding (1995) and Granger et al. (2000) listed a number of them. One of them, the socalled Taylor effect, was also researched by He and Teräsvirta (1999), as well as Malmsten and Teräsvirta (2004). For a series possessing this stylized fact, the autocorrelations of absolute values are raised to a positive power, peaking when the power equals unity. Another common observation is that the return series have high kurtosis and, at the same time, the autocorrelation coefficients of squared observations are low. This stylized fact and its presence in high-frequency financial series were discussed in Teräsvirta and Zhao (2007) and in Malmsten and Teräsvirta (2004).

In recent times, Kim and White (2004) considered robust measures of skewness and kurtosis for return series. Their conclusion was that the stylized facts of negative skewness and high kurtosis in these series, as compared to standard skewness and kurtosis estimates, may be too readily accepted. They recommended the use of robust measures instead. This paper, in keeping with the aforementioned authors, reconsiders stylized facts using robust measures of kurtosis and autocorrelation, and studies both the Taylor effect and the kurtosis-autocorrelation relationship.

Although the statistical properties of stock and commodity prices and market indexes have been studied using data from various markets and instruments for more than half a century, the availability of large data sets of high-frequency price series and the application of computer-intensive methods for analysing their properties have opened up new horizons to empirical finance researchers in the last decade, and have contributed to the consolidation of a data-based approach in financial modelling. The study of these new data sets has led to the settling of a 
number of long-standing disputes regarding the nature of the data, but at the same time it has also generated new challenges, not least of which is to be able to capture, in a synthetic and meaningful fashion, the information and properties contained within this huge amount of data. A set of properties, common across many instruments, markets and time periods, has been observed by independent studies and classified as 'stylized facts'. The aim of the present paper is to focus more on the properties of empirical data than on those of statistical models, and introduce the reader to some new insights provided by methods based on statistical techniques that have recently been applied to empirical finance.

The property of asymmetry is most notable in equity returns, and refers to the fact that there tend to be greater increases in return volatility following negative return shocks than positive ones. This was first noted by Black (1976), who argued that negative return shocks increase financial leverage, implying a riskier return on equity given an unchanged stream of cash flows.

In this paper, we explain the main stylized facts of financial returns in the most important American, Chinese and European financial markets, and we focus on one particular fact, known as "leverage effect" in the financial literature.

To explain the leverage effect, or the asymmetric pattern of volatility (good and bad news have different effects on conditional variance), we contribute to the literature with a threshold asymmetric autoregressive stochastic volatility model (TA-ARSV). This model was initially proposed by So et al. in 2002 and later developed by Garcia and Minguez in 2009. The TA-ARSV model adds two new parameters to the ARSV model, measuring the effect of positive and negative returns on volatility. Among other advantages, the TA-ARSV model does not require the assumption of correlation between the innovations of the returns and volatility equations to capture the leverage effect, as other ARSV models do. The strength of our proposed strategy to explain the aforementioned stylized fact for electricity prices or pollution levels, was empirically demonstrated by Montero et al. (2011). This paper compares the results obtained by TA-ARSV with ARSV and traditional asymmetric GARCH models for 20 financial index returns. As expected, the results confirm that for financial returns, the TA-ARSV model is more effective than the other competing models.

This paper is structured as follows. Following on from introduction, Section 2 shows the data and some descriptive statistics. Section 3 analyses the main stylized fact of 20 different indexes from several countries around the world. Section 4 defines four asymmetric GARCH models and two stochastic volatility models. Section 5 explains the main results and section 6 provides some concluding remarks. 


\section{Data}

The data considered in this paper consists of index data for the most important markets in the world. Specifically, we used the following 20 indexes: Dow Jones, Nasdaq 100, Nasdaq Composite and S\&P 500 (United States); Bovespa (Brazil); Merval (Argentina); NIKKEI (Japan); HJI, SHCOMP, SHSZ300 and SZCOMP (China); PSI (Portugal); IBEX35 (Spain); FTSE (UK); MIB (Italy); CAC (France); SWISS (Switzerland); DAX (Germany); AEX (the Netherlands) and EUROSTOXX50 (SX5E) from 12 Eurozone countries (Austria, Belgium, Finland France, Germany, Greece, Ireland, Italy, Luxembourg, the Netherlands, Portugal and Spain).

The data of indexes were downloaded from Bloomberg ${ }^{1}$ and for all indexes we considered the daily closing value. The sample period analysed for these data is from $03 / 01 / 2000$ to $04 / 02 / 2014$.

Returns $\left(Y_{t}\right)$ are calculated as first difference of natural logarithm of price indexes in two consecutive trading days, that is,

$$
Y_{t}=100^{*}\left(\log I_{t}-\log I_{t-1}\right)
$$

where $I_{t}$ is the value of the index at time point $t$.

To analyse certain characteristics of the 20 return series, some descriptive statistics appear in Table 1. These descriptive statistics confirm that the mean is statistically zero in all cases. The biggest standard deviation is for the majority of indexes from USA and South America. All returns exhibit an excess kurtosis (this implies that all of them have leptokurticity).

There is a negative skewness in the majority of indexes, except in the following five cases: CAC, IBEX35, Nasdaq 100, Nasdaq Composite and SX5E (where positive skewness is observed). This indicates that the returns distribution is not distributed normally. Indeed, the Jarque-Bera test for normality shows the rejection of normality for all returns at the $5 \%$ significance level.

Finally, the Ljüng-Box $Q$ test on the squared return series for $10^{\text {th }}$ and $20^{\text {th }}$ order serial correlation rejects the null hypothesis; this implies that the stochastic volatility models are needed to explain the behaviour of this type of series. It is also worth noting that the daily swings can be quite substantial, exemplified by the values on the minimum and maximum observations.

${ }^{1}$ http://www.bloomberg.com/ 
Table 1. Summary Statistics for the return indexes

\begin{tabular}{|c|c|c|c|c|c|c|c|c|c|}
\hline Index & Mean & Std. Devn & Skew. & Kurt. & Min & Max & $\mathrm{JB}$ & Qs(10) & $Q s(50)$ \\
\hline AEX & -0.011 & 0.693 & -0.063 & 5.856 & -4.165 & 4.355 & $4305.8^{*}$ & $2343.7^{*}$ & $5648.6^{\star}$ \\
\hline BOVESPA & 0.013 & 0.817 & -0.157 & 4.036 & -5.253 & 5.940 & $2362.0^{*}$ & $1795.3^{\star}$ & $3860.8^{*}$ \\
\hline CAC & -0.004 & 0.658 & 0.025 & 4.842 & -4.113 & 4.601 & $3593.2^{*}$ & $1806.5^{\star}$ & $3052.5^{\star}$ \\
\hline DAX & 0.003 & 0.676 & -0.005 & 4.493 & -3.854 & 4.689 & $3093.8^{*}$ & $1961.3^{\star}$ & $5198.0^{\star}$ \\
\hline DJI & 0.003 & 0.540 & -0.054 & 7.498 & -3.561 & 4.563 & $7932.7^{*}$ & $2402.4^{*}$ & $6361.1^{*}$ \\
\hline FTSE & -0.0001 & 0.555 & -0.138 & 5.811 & -4.024 & 4.075 & $4835.4^{*}$ & $2419.9^{*}$ & $5503.6^{\star}$ \\
\hline HSI & 0.002 & 0.670 & -0.066 & 8.296 & -5.898 & 5.822 & $10547^{*}$ & $2263.1^{*}$ & $4677.9^{\star}$ \\
\hline IBEX35 & -0.002 & 0.661 & 0.110 & 5.072 & -4.163 & 5.855 & $3949.5^{*}$ & $1269.4^{*}$ & $1944.1^{*}$ \\
\hline MERVAL & 0.029 & 0.933 & -0.159 & 4.858 & -5.624 & 6.999 & $3386.0^{*}$ & $1470.7^{\star}$ & $2990.1^{*}$ \\
\hline MIB 30 & -0.010 & 0.666 & -0.052 & 4.916 & -3.829 & 4.675 & $3411.2^{*}$ & $520.1^{*}$ & $3519.0^{*}$ \\
\hline NASDAQ100 & -0.0019 & 0.860 & 0.195 & 5.630 & -4.827 & 7.471 & $4590.1^{*}$ & $1875.1^{*}$ & $5795.06^{*}$ \\
\hline $\begin{array}{l}\text { NASDAQ } \\
\text { COMPOSITE }\end{array}$ & -0.0067 & 0.804 & 0.066 & 4.252 & -4.416 & 5.756 & $2271.9^{*}$ & $1512.8^{*}$ & $4572.08^{*}$ \\
\hline NIKKEY & -0.003 & 0.664 & -0.434 & 6.746 & -5.259 & 5.747 & $7089.8^{*}$ & $2861.8^{\star}$ & $4283.4^{*}$ \\
\hline PSI & 0.001 & 0.521 & -0.135 & 8.849 & -4.507 & 4.428 & $8580.9^{*}$ & $915.95^{\star}$ & $1533.8^{*}$ \\
\hline SHCOMP & 0.004 & 0.669 & -0.086 & 4.785 & -4.019 & 4.082 & $3513.4^{*}$ & $461.7^{\star}$ & $708.08^{\star}$ \\
\hline SHSZ300 & -0.002 & 0.558 & -0.016 & 6.009 & -3.521 & 4.685 & $4532.0^{*}$ & $473.12^{\star}$ & $1538.0^{*}$ \\
\hline SPX & 0.002 & 0.559 & -0.176 & 8.105 & -4.112 & 4.7586 & $10084^{*}$ & $2882.6^{\star}$ & $5020.1^{\star}$ \\
\hline SWISS & 0.007 & 0.738 & -0.230 & 3.714 & -4.210 & 3.897 & $1758.6^{*}$ & $2350.1^{*}$ & $4296.05^{\star}$ \\
\hline SX5E & -0.005 & 0.666 & 0.020 & 4.428 & -3.564 & 4.533 & $3004.9^{*}$ & $1917.0^{*}$ & $4858.9^{\star}$ \\
\hline SZCOMP & 0.011 & 0.736 & -0.367 & 3.659 & -3.878 & 4.014 & $2134.6^{*}$ & $570.27^{*}$ & $1520.8^{*}$ \\
\hline
\end{tabular}

$J B$ is the value of Jarque-Bera test for normality; $Q_{s}(10)$ y $Q_{s}(20)$ are the values of the Ljüng-Box $Q$ test of autocorrelation in squared return series using 10 and 20 lags. * indicates rejection at the $5 \%$ significance level.

\section{Characteristics of stock market indexes returns}

The financial index returns have similar empirical stylized facts regardless of the stock market analysed, see Cont (2001), Takayasu et al. (2006). These characteristics are:

1. Absence of autocorrelations: Returns are uncorrelated because the autocorrelation function (ACF) frequently has no significant coefficients. We will illustrate this, in Figure 1, with the ACF of the four index returns: SHCOMP, BOVESPA, MIB 30 and NIKKEI.

Figure 1. ACF of returns
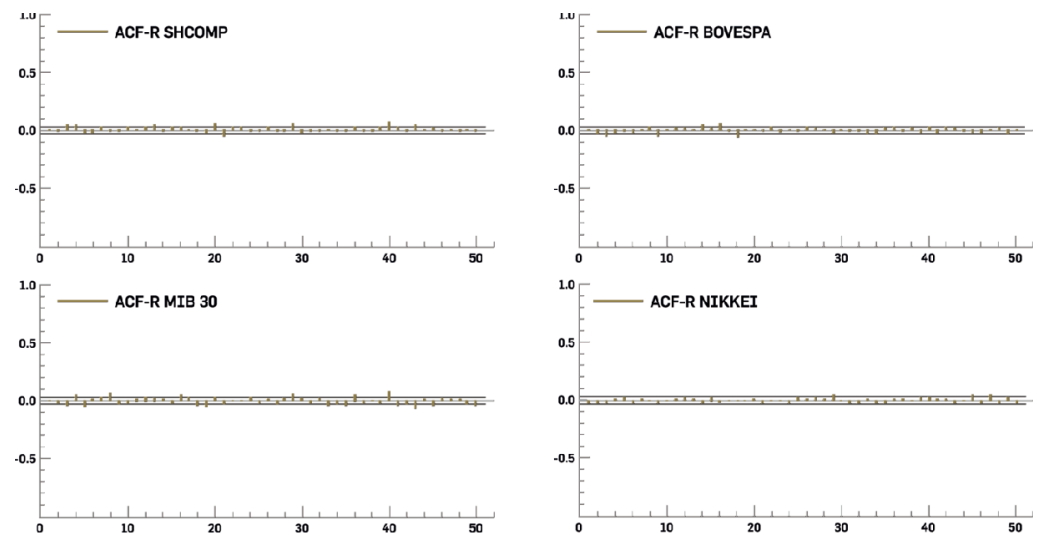
2. Returns are not independent because their non-linear transformations are positively correlated, that is the reason why the autocorrelation functions report significant squared returns, as can be seen in Figure 2. This implies correlation of the volatility of the returns among different periods. Also, these correlations are positive in all returns, which means that volatility has a pattern of behaviour and can therefore be modelled.

\section{Figure 2. ACF of squared returns}
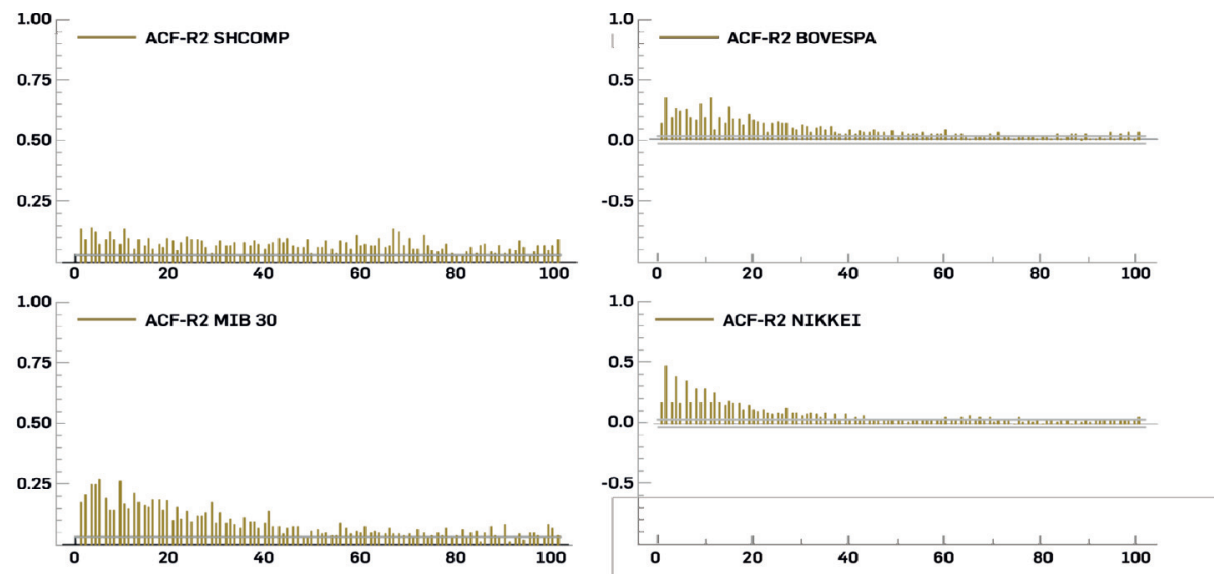

3. Slow decay of autocorrelation in asset returns: As a function of time lag, effect as measured using squared returns slowly decays. This is sometimes interpreted as a sign of long-range dependence or persistence in volatility, Ding et al. (1993) as can be seen in Figure 2 in the squared returns of SHCOMP and MIB 30.

Figure 3. Returns of different indexes
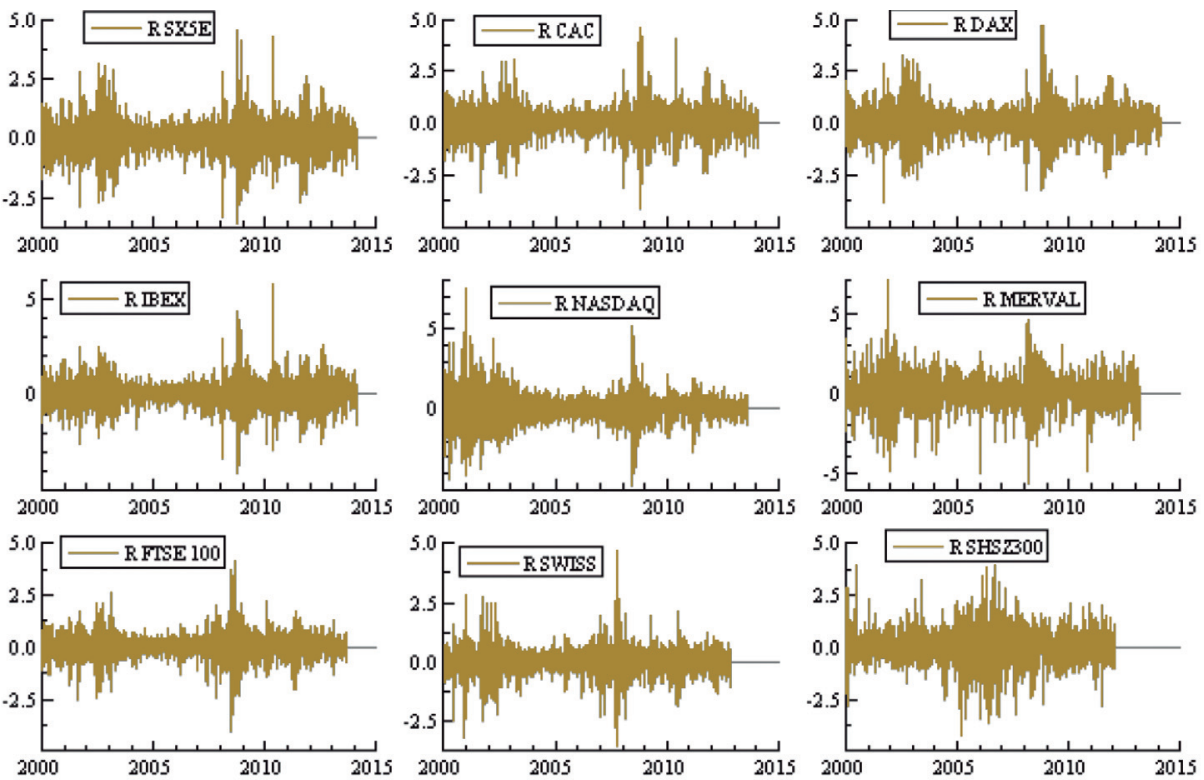
4. Volatility Clustering: Meaning that conditional variance is not constant, since some periods with high variability alternate with periods with low variability, see Figure 3 .

5. Returns oscillate around a constant low level close to zero, see Figure 3 and Table 1.

6. Heavy tails: The unconditional distribution of returns displays a power-law tail gain/loss asymmetry: Large downward movements are more frequent than equivalent upward ones. This means that the returns are not normal, see Figure 4 and Table 1.

\section{Figure 4. Histogram and QQ-plot of different indexes returns}
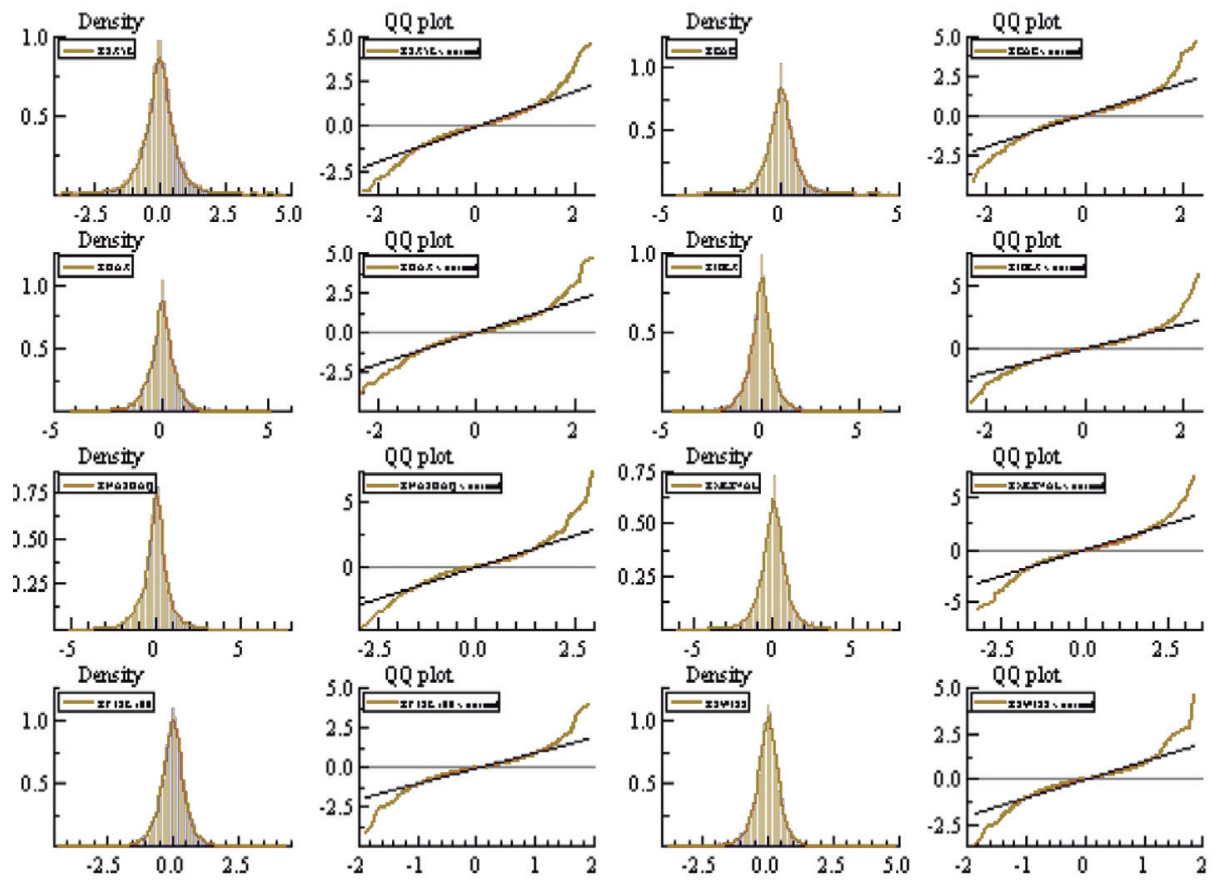

7. Returns are leptokurtic, and with heavy tails due to extreme values.

8. Aggregational Gaussianity: As one increases the time scales over which the returns are being measured, the probability distribution of returns tends towards a Gaussian distribution. But, the distribution of returns is not the same for different time scales. This implies that when we compare the distribution of daily returns with monthly, quarterly or annual returns, we observe that the last ones are more similar to a Normal distribution.

9. Intermittency: Presence of "irregular bursts" in time series at both fine/coarse time scales.

10. Volume/volatility correlation: Trading volume is correlated with all measures of volatility.

11. Taylor effect. In 1986 Taylor observed that the empirical sample autocorrelations of absolute returns, $\left|Y_{t}\right|$, are usually larger than those of squared returns, $Y_{t}^{2}$, see Figure 5. 
Figure 5. ACF of absolute value returns and squared returns
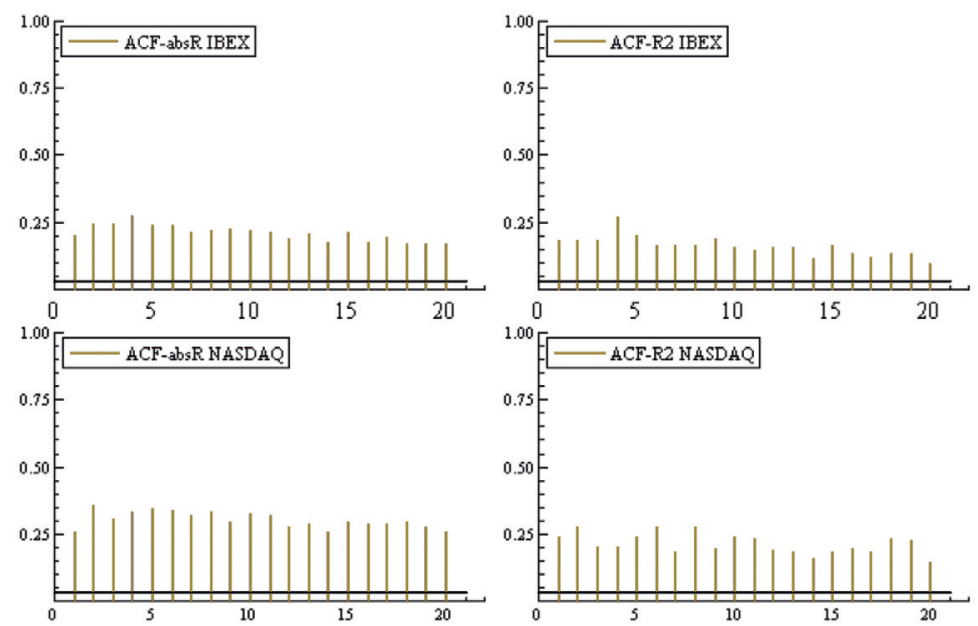

12. Leverage effect: Most measures of volatility and asset returns are negatively correlated with asset returns. This can be done in various ways, and two possible ways would be to: a) to look at the 'spot skew' from the options data; b) to show that asymmetric GARCH provides a better fit than a simple GARCH.

These stylized facts show that the behaviour of volatility presents certain regularities and we can therefore model the dynamics of volatility. In this case, our interest focuses on determining if the pattern of volatility for positive and negative shocks of the same magnitude is different. Consequently, the next section proposes a different model to capture a potential leverage effect in volatility.

\section{Model framework}

To date, the ARCH and GARCH framework by Engle (1982) and Bollerslev (1986), stands out as the single most important tool when it comes to understanding and modelling the dynamics of financial volatility. Since the birth of the basic models, the literature has exploded with variety of different extensions primarily designed to cope with the stylized facts, see Harvey and Shephard (1996), Andersen et al. (2003).

There are many models used to investigate the dynamics of volatility. This section focuses on certain models to explain the potential asymmetry in volatility. The asymmetry property is most notable for equity returns and it refers to the fact that volatility tends to increase more following negative return shocks than positive ones. Several alternatives for incorporating asymmetric effects have been proposed in the literature. 
The asymmetric GARCH model (AGARCH) of Engle and Rothschild (1990) was one of the first asymmetric models. Another commonly employed alternative that includes asymmetry is the exponential GARCH (EGARCH) model of Nelson (1991). The most popular one appears to be the asymmetric threshold GARCH (GJRGARCH) of Glosten et al. (1993) and Zakoïan (1994) and the asymmetric potential GARCH model (APARCH) of Ding et al. (1993). However, the stochastic volatility model is another type of model used to estimate the leverage effect in volatility. One of the most important models is the threshold asymmetric autoregressive stochastic volatility model (TA-ARSV) of So et al. (2002) and Garcia and Minguez (2009). This model is a generalization of the autoregressive stochastic volatility model developed by Taylor (1986). These six models are compared to select the best model to describe the characteristics of volatility.

All these models have the same mean equation:

$$
Y_{t}=\sigma_{t} \varepsilon_{t} \quad \varepsilon_{t} \sim \text { i.i.d. } N(0,1)
$$

where $Y_{t}$ are the daily returns of the corresponding stock exchange index under consideration, $\sigma_{t}^{2}$ represents the conditional variance, and $\varepsilon_{t}$ the innovations, which are independent and follow a Gaussian distribution with zero mean and unit variance.

Although the above-mentioned models have a common mean equation, they differ in the conditional variance specification. In light of both the autocorrelation and partial autocorrelation functions of returns, we propose to explain the dynamics of index returns volatility using $\operatorname{AGARCH}(1,1), \operatorname{GJR}-\operatorname{GARCH}(1,1), \operatorname{EGARCH}(1,1), \operatorname{APARH}(1,1)$, ARSV(1) and TA-ARSV(1). The specification of the conditional variance in the abovementioned models is reported in Table 2.

\section{Table 2. Models for the specification of the conditional variance}

\begin{tabular}{ll}
\hline Models & Conditional variance equation \\
\hline $\operatorname{AGARCH}(1,1)$ & $\sigma_{t}^{2}=\alpha_{0}+\alpha_{1}\left(y_{t-1}-\gamma\right)^{2}+\beta \sigma_{t-1}^{2}$ \\
\hline $\operatorname{GJR}-G A R C H(1,1)$ & $\sigma_{t}^{2}=\alpha_{0}+\alpha_{1} \varepsilon_{t-1}^{2}+\gamma \varepsilon_{t-1}^{2} d_{t-1}+\beta \sigma_{t-1}^{2}$ \\
\hline $\operatorname{EGARCH}(1,1)$ & $\log \sigma_{t}^{2}=\omega+\beta \log \sigma_{t-1}^{2}+\alpha \frac{\left|\varepsilon_{t-1}\right|}{\sqrt{\sigma_{t-1}}}-\alpha \sqrt{\frac{2}{\pi}}+\gamma \frac{\varepsilon_{t-1}}{\sqrt{\sigma_{t-1}}}$ \\
\hline $\operatorname{APARCH}$ & $\sigma_{t}^{\delta}=\alpha_{0}+\alpha_{1}\left(\left|\varepsilon_{t-1}\right|+\gamma \varepsilon_{t-1}\right)^{\delta}+\beta \sigma_{t-1}^{2}$ \\
\hline $\operatorname{ARSV(1)}$ & $h_{t}=\phi h_{t-1}+\eta_{t}$ \\
\hline $\operatorname{TA-ARSV(1)}$ & $h_{t}=\left(\phi_{11} I_{1 t}+\phi_{12} I_{2 t}\right) h_{t-1}+\eta_{t}$ \\
\hline
\end{tabular}


The leverage effect is estimated with different parameters in the proposed models. For example:

- $\gamma$ is the parameter in the AGARCH model to account for the asymmetric behaviour of the volatility. If $\gamma$ is significant and not equal to zero then the leverage effect exists. Some restrictions are incorporated into the parameter of the model because the volatility needs to be positive. These restrictions are: $\alpha_{0}>0, \alpha_{1} \geq 0, \beta \geq 0$ and $\alpha_{1}+\beta<1$.

- $d_{t-1}$ is the variable incorporated into the GJR-GARCH model. This variable is defined as follows: $d_{t-1}=\left\{\begin{array}{ll}1 & \varepsilon_{t-1}<0 \\ 0 & \varepsilon_{t-1} \geq 0\end{array}\right.$, where, in the market, the good and bad news are represented by $\varepsilon_{t-1} \geq 0$ and $\varepsilon_{t-1}<0$, respectively. Thus, $\alpha_{1}$ is the effect on volatility in case of good news and $\left(\alpha_{1}+\gamma\right)$ is the impact on volatility of bad news. In these two specifications $\alpha_{0}$ is positive and both $\alpha_{1}$ and $\beta$ are nonnegative (to guarantee a nonnegative variance). Moreover, the condition $\alpha_{1}+\beta<1$ is satisfied to ensure the stationarity of process $Y_{t}$.

- $\gamma$ is the parameter in the EGARCH model used to explain the leverage effect. This model has been expressed in logarithmic form in order to guarantee a positive variance without imposing the typical constrains of parameters: $w>0, \alpha \geq 0, \beta \geq 0$. In this model, $(\alpha+\gamma)$ is the effect on volatility when the returns are positive in a previous period, whereas $(\gamma-\alpha)$ is the corresponding effect when $y_{t-1}<0$.

- $\gamma$ is the parameter that reflects the leverage effect in the APARCH model. A positive (respectively negative) value of the $\gamma$ means that past negative (respectively positive) shocks have a deeper impact on current conditional variance than past positive shocks. The $\delta$ parameter $(\delta>0)$ plays the role of a Box-Cox transformation of the conditional standard deviation $\sigma_{t}$.

- The ARSV(1) is not an asymmetric model but it is important because the TA-ARSV model is a generalization of it. In this model, $\sigma_{t}=\sigma_{*} \exp \left(0.5 h_{t}\right)$, where $h_{t}$ is the logvolatility, $h_{t}=\log \left(\sigma_{t}^{2}\right)$, and $\sigma_{*}$ is a positive scale factor in the mean equation to avoid including a constant in the log-volatility equation. $\eta_{t}$ is a white noise process and follows a Gaussian distribution with zero mean and variance $\sigma_{\eta}^{2}$. Both $\varepsilon_{t}$ and $\eta_{t}$ are independent, $E\left(\varepsilon_{t}, \eta_{t}\right)=0, \forall t$, s. This way of specifying the conditional variance guarantees a positive variance.

We introduce the TA-ARSV(1) model in this paper to describe the dynamics of the volatility in the series of indexes returns. The mean equation is defined as in the ARSV(1) model, but the way of specifying the conditional variance is different. 
To estimate the leverage effect of the volatility it is necessary to establish a threshold that changes the value of the parameters in the model. Therefore, obtaining the TAARSV model from an ARSV model implies:

a) Adding two new parameters, $\phi_{11}$ and $\phi_{12}$, which measure the effect of the positive and negative returns on volatility, respectively.

b) Adding two indicator variables, $\mathrm{I}_{1 t}$ and $\mathrm{I}_{2 t}$, defined as follows:

$$
\begin{aligned}
& \mathbf{I}_{1 t}= \begin{cases}1 & \text { when the return is zero or positive } \\
0 & \text { otherwise }\end{cases} \\
& \mathbf{I}_{2 t}= \begin{cases}1 & \text { when the return is negative } \\
0 & \text { otherwise }\end{cases}
\end{aligned}
$$

Therefore, in this model the volatility is defined as an exponential function. Thus, the model is not linear. However, for estimation purposes, it can be expressed in a linear form by squaring the mean equation and taking logarithms. Following Sandmann \& Koopman (1998), we express the specification in a space state form to obtain the following linear model:

$$
\left(\begin{array}{c}
h_{t+1} \\
Y_{t}
\end{array}\right)=\delta_{t}+\Phi h_{t}+u_{t}
$$

where $Y_{t}=\log \left(\gamma_{t}^{2}\right)$ and

$$
\left.\mathbf{u}_{t} \sim \text { i.i.d. N( } 0, \boldsymbol{\Omega}_{T}\right), \quad \boldsymbol{\delta}_{t}=\left(\begin{array}{c}
0 \\
\ln \sigma_{*}^{2}
\end{array}\right), \quad \boldsymbol{\Phi}=\left(\begin{array}{c}
\phi_{11} \mathrm{I}_{1 t}+\phi_{12} \mathrm{I}_{2 t} \\
1
\end{array}\right), \quad \boldsymbol{\Omega}_{T}=\left(\begin{array}{cc}
\sigma_{\eta}^{2} & 0 \\
0 & \frac{\pi^{2}}{2}
\end{array}\right)
$$

The unknown likelihood function of a TA-ARSV(1) model, which is a non-Gaussian model, was evaluated by using the Monte Carlo method, approximating the non-Gaussian model by importance sampling - see Durbin and Koopman (1997), Sandmann and Koopman (1998).

The estimation of the parametric vector $\left(\phi_{11}, \phi_{12}, \sigma_{*}, \sigma_{\eta}^{2}\right)$ requires the following algorithm:

a)An approximated Gaussian model is obtained from an initial vector of parameters of the model. The initial values of the parameters are estimated from the available information for each return.

b)The Gaussian likelihood function for the approximated model is calculated using the Kalman filter. 
c) The process is repeated until the desired level of convergence is achieved. At this level, the likelihood function reaches its maximum value.

Finally, the parametric vector that maximizes the simulated likelihood function is obtained by using the Broyden-Fletcher-Goldfarb-Shanno (BFGS) method, a wellknown method for solving unconstrained Nonlinear optimization problems.

The leverage effect is checked by testing the null hypothesis: $\mathrm{H}_{0}: \phi_{11}=\phi_{12}$ (ARSV model) versus the alternative one: $\mathrm{H}_{1}: \phi_{11} \neq \phi_{12}$ (TA-ARSV(1) model). Since the null and the alternative hypotheses refer to two nested models, this strategy allows for the implementation of a likelihood ratio test, the test statistic being $\lambda=-2\left(\log L^{R}-\log L\right)$, which follows (under the null) a chi-squared distribution with one degree of freedom.

If the null hypothesis is not rejected, then there is no evidence of the leverage effect on volatility. In such a case, the ARSV(1) model might be preferred. On the other hand, the rejection of the null hypothesis suggests that the effects of positive and negative shocks on the dynamics of volatility are different.

The estimation procedure for the TA-ARSV(1) model was developed by the authors using Ox 4.1 programming language and SsfPack 2.3.

\section{Empirical evidence}

The results obtained for the returns of the 20 indexes and the six different models estimated are shown in Tables 3, 4, 5, 6 and 7.

As we can see in Table 3, the estimation of AGARCH $(1,1)$ model shows that the leverage effect exits in all cases except in two Asian indexes, SHSZ300 and SZCOMP, where the $\gamma$ parameter is not statistically significant at the $5 \%$ significance level. This parameter is positive in all cases, which implies that the influence on volatility of negative returns is greater than that of positive ones.

Also, the highest value of the $\gamma$ parameter is found for South American indexes (BOVESPA and MERVAL) and the lowest for PSI (Portugal) and SHCOMP (China). In the case of European indexes, the leverage effect is higher in the indexes from the North of Europe (CAC and DAX) than the South (MIB 30). The asymmetric pattern of North American indexes is high and closer to South American ones.

The estimated persistence $(\alpha+\beta)$ is close to one in all cases but the process is stationary. This implies that if volatility is high in one period, it will be high in the next period as well. 
Table 3. Estimated results with an $\operatorname{AGARCH}(1,1)$

\begin{tabular}{|c|c|c|c|c|}
\hline Index & $\alpha_{0}$ & $\alpha_{1}$ & $\beta$ & $\gamma$ \\
\hline AEX & $\begin{array}{l}4.702 \mathrm{E}-13 \\
(0.000)\end{array}$ & $\begin{array}{c}0.090424 \\
(7.46)\end{array}$ & $\begin{array}{l}0.889009 \\
(66.3)\end{array}$ & $\begin{array}{l}0.269845 \\
(9.04)\end{array}$ \\
\hline BOVESPA & $\begin{array}{l}0.005070 \\
(1.26)\end{array}$ & $\begin{array}{c}0.061517 \\
(5.58)\end{array}$ & $\begin{array}{c}0.90888 \\
(47.4)\end{array}$ & $\begin{array}{c}0.460923 \\
(3.18)\end{array}$ \\
\hline CAC & $\begin{array}{c}9.055 \mathrm{E}-14 \\
(0.000)\end{array}$ & $\begin{array}{c}0.086242 \\
(8.04)\end{array}$ & $\begin{array}{c}0.885682 \\
(65.6)\end{array}$ & $\begin{array}{c}0.335813 \\
(9.49)\end{array}$ \\
\hline DAX & $\begin{array}{c}2.465 \mathrm{E}-14 \\
(0.4416)\end{array}$ & $\begin{array}{c}0.084345 \\
(8.27)\end{array}$ & $\begin{array}{c}0.888641 \\
(68.2)\end{array}$ & $\begin{array}{c}0.332248 \\
(9.18)\end{array}$ \\
\hline DJI & $\begin{array}{c}\text { 1.6009E-6 } \\
(3.4 \mathrm{E}-5)\end{array}$ & $\begin{array}{c}0.091485 \\
(8.59)\end{array}$ & $\begin{array}{c}0.882538 \\
(70.4)\end{array}$ & $\begin{array}{l}0.250725 \\
(9.29)\end{array}$ \\
\hline FTSE & $\begin{array}{l}5.44 \mathrm{E}-13 \\
(0.0000)\end{array}$ & $\begin{array}{c}0.082614 \\
(7.31)\end{array}$ & $\begin{array}{c}0.894106 \\
(64.0)\end{array}$ & $\begin{array}{c}0.251618 \\
(8.97)\end{array}$ \\
\hline HSI & $\begin{array}{l}5.5619 E-5 \\
(0.405)\end{array}$ & $\begin{array}{c}0.0625118 \\
(6.53)\end{array}$ & $\begin{array}{c}0.925463 \\
(82.1)\end{array}$ & $\begin{array}{c}0.274925 \\
(5.61)\end{array}$ \\
\hline IBEX & $\begin{array}{c}1.5544 \mathrm{E}-13 \\
(40.1)\end{array}$ & $\begin{array}{c}0.093307 \\
(7.16)\end{array}$ & $\begin{array}{c}0.883052 \\
(57.4)\end{array}$ & $\begin{array}{c}0.30817 \\
(8.77)\end{array}$ \\
\hline MERVAL & $\begin{array}{c}0.01917 \\
(2.70)\end{array}$ & $\begin{array}{l}0.088540 \\
(5.30)\end{array}$ & $\begin{array}{c}0.874906 \\
(38.9)\end{array}$ & $\begin{array}{c}0.34998 \\
(2.80)\end{array}$ \\
\hline MIB 30 & $\begin{array}{c}\text { 4.485E-14 } \\
(1566)\end{array}$ & $\begin{array}{c}0.082525 \\
(1.001 E+27)\end{array}$ & $\begin{array}{c}0.901637 \\
(1.09 E+28)\end{array}$ & $\begin{array}{c}0.266413 \\
(8.28 E+34)\end{array}$ \\
\hline NASDAQ100 & $\begin{array}{c}3.45 E-14 \\
(3436)\end{array}$ & $\begin{array}{l}0.077386 \\
(3.4 E+28)\end{array}$ & $\begin{array}{c}0.906761 \\
(4.13 E+28)\end{array}$ & $\begin{array}{c}0.30128 \\
(1.03 E+36)\end{array}$ \\
\hline NASDAQ COMPOSI & $\begin{array}{c}1.9509 E-14 \\
(2.64 E+16)\end{array}$ & $\begin{array}{c}0.07892 \\
(9.99 E+4)\end{array}$ & $\begin{array}{c}0.902474 \\
(1.14 \mathrm{E}+42) \\
\end{array}$ & $\begin{array}{c}0.301031 \\
(2.82 E+43)\end{array}$ \\
\hline NIKEY & $\begin{array}{c}0.003901 \\
(1.50)\end{array}$ & $\begin{array}{l}0.091249 \\
(7.71)\end{array}$ & $\begin{array}{c}0.882350 \\
(60.4)\end{array}$ & $\begin{array}{l}0.291173 \\
(2.78)\end{array}$ \\
\hline PSI & $\begin{array}{c}0.0019526 \\
(2.25)\end{array}$ & $\begin{array}{c}0.116767 \\
(6.24)\end{array}$ & $\begin{array}{c}0.87206 \\
(45.0)\end{array}$ & $\begin{array}{c}0.117767 \\
(3.56)\end{array}$ \\
\hline SHCOMP & $\begin{array}{c}0.0043566 \\
(2.25)\end{array}$ & $\begin{array}{c}0.057728 \\
(4.39)\end{array}$ & $\begin{array}{l}0.931029 \\
(55.9)\end{array}$ & $\begin{array}{c}0.119456 \\
(2.08)\end{array}$ \\
\hline SHSZ300 & $\begin{array}{c}0.005408 \\
(2.20)\end{array}$ & $\begin{array}{c}0.061661 \\
(4.57)\end{array}$ & $\begin{array}{c}0.928602 \\
(55.6)\end{array}$ & $\begin{array}{c}0.086765 \\
(1.59)\end{array}$ \\
\hline SPX & $\begin{array}{l}0.000001 \\
(5.09)\end{array}$ & $\begin{array}{l}0.084826 \\
(9.24)\end{array}$ & $\begin{array}{c}0.889012 \\
(76.7)\end{array}$ & $\begin{array}{c}0.264190 \\
(9.16)\end{array}$ \\
\hline SWISS & $\begin{array}{c}2.622 \mathrm{E}-12 \\
(322.0)\end{array}$ & $\begin{array}{c}0.105017 \\
(8.71)\end{array}$ & $\begin{array}{c}0.864193 \\
(64.4)\end{array}$ & $\begin{array}{c}0.268472 \\
(9.61)\end{array}$ \\
\hline SX5E & $\begin{array}{c}-1.27 \mathrm{E}-12 \\
(32.6)\end{array}$ & $\begin{array}{c}0.09272 \\
(7.86)\end{array}$ & $\begin{array}{c}0.877842 \\
(58.9)\end{array}$ & $\begin{array}{c}0.33396 \\
(10.1)\end{array}$ \\
\hline SZCOMP & $\begin{array}{c}0.005283 \\
(2.41)\end{array}$ & $\begin{array}{c}0.0606525 \\
(4.83)\end{array}$ & $\begin{array}{l}0.930804 \\
(65.9)\end{array}$ & $\begin{array}{c}0.0452641 \\
(0.75)\end{array}$ \\
\hline
\end{tabular}

$t$-value is in parentheses.

As can be seen in Table 4, the GJR-GARCH $(1,1)$ model is able to detect the leverage effect for all indexes (except SHSZ300 and SZCOMP) because at a 5\% significance level the $\gamma$ parameter is positive and statistically significant. This implies that negative returns exert a greater influence on volatility than positive ones. 
Furthermore, the highest values of the $\gamma$ parameter are for European and North American indexes and the lowest are for South American and Asian indexes.

Table 4. Estimated results with a GJR-GARCH(1,1)

\begin{tabular}{|c|c|c|c|c|}
\hline \multicolumn{5}{|c|}{ GJR-AGARCH $(1,1)$ model estimation } \\
\hline Index & $\alpha_{0}$ & $\alpha_{1}$ & $\beta$ & $\gamma$-GJR \\
\hline AEX & $\begin{array}{c}-0.004108 \\
(-0.5278)\end{array}$ & $\begin{array}{c}-0.023177 \\
(-3.385)\end{array}$ & $\begin{array}{c}0.924264 \\
(86.62)\end{array}$ & $\begin{array}{c}0.175192 \\
(8.587)\end{array}$ \\
\hline BOVESPA & $\begin{array}{c}0.004898 \\
(0.410)\end{array}$ & $\begin{array}{c}0.008197 \\
(1.114)\end{array}$ & $\begin{array}{c}0.92191 \\
(50.32)\end{array}$ & $\begin{array}{c}0.093748 \\
(3.981)\end{array}$ \\
\hline CAC & $\begin{array}{c}-0.004361 \\
(-0.573)\end{array}$ & $\begin{array}{c}-0.022002 \\
(-3.394)\end{array}$ & $\begin{array}{c}0.926012 \\
(80.80)\end{array}$ & $\begin{array}{c}0.167796 \\
(7.659)\end{array}$ \\
\hline DAX & $\begin{array}{c}0.003865 \\
(0.6376)\end{array}$ & $\begin{array}{l}-0.1737 \\
(-2.037)\end{array}$ & $\begin{array}{c}0.92093 \\
(80.47)\end{array}$ & $\begin{array}{c}0.167422 \\
(7.933)\end{array}$ \\
\hline DJI & $\begin{array}{c}0.003865 \\
(0.6376)\end{array}$ & $\begin{array}{c}-0.01737 \\
(-2.037)\end{array}$ & $\begin{array}{c}0.920930 \\
(80.47)\end{array}$ & $\begin{array}{c}0.167422 \\
(7.933)\end{array}$ \\
\hline FTSE & $\begin{array}{c}-0.011286 \\
(-0.2058)\end{array}$ & $\begin{array}{c}-0.014568 \\
(-1.981)\end{array}$ & $\begin{array}{c}0.915206 \\
(78.57)\end{array}$ & $\begin{array}{c}0.166419 \\
(7.346)\end{array}$ \\
\hline HSI & $\begin{array}{c}0.0619 \\
(0.7545)\end{array}$ & $\begin{array}{c}0.013931 \\
(2.478)\end{array}$ & $\begin{array}{c}0.935835 \\
(124.5)\end{array}$ & $\begin{array}{c}0.076536 \\
(5.236)\end{array}$ \\
\hline IBEX & $\begin{array}{c}0.006458 \\
(0.8321)\end{array}$ & $\begin{array}{c}-0.006946 \\
(-0.9937)\end{array}$ & $\begin{array}{c}0.925906 \\
(72.35)\end{array}$ & $\begin{array}{c}0.140675 \\
(6.684)\end{array}$ \\
\hline MERVAL & $\begin{array}{c}0.03189 \\
(2.346)\end{array}$ & $\begin{array}{c}0.05669 \\
(4.674)\end{array}$ & $\begin{array}{c}0.879261 \\
(47.01)\end{array}$ & $\begin{array}{c}0.061312 \\
(2.984)\end{array}$ \\
\hline MIB 30 & $\begin{array}{c}-0.001432 \\
(-0.186)\end{array}$ & $\begin{array}{c}0.001326 \\
(0.1716)\end{array}$ & $\begin{array}{c}0.928749 \\
(83.39)\end{array}$ & $\begin{array}{c}0.120708 \\
(6.043)\end{array}$ \\
\hline NASDAQ100 & $\begin{array}{c}0.011154 \\
(1.273)\end{array}$ & $\begin{array}{c}-0.004653 \\
(-0.6173)\end{array}$ & $\begin{array}{c}0.934643 \\
(87.21)\end{array}$ & $\begin{array}{c}0.123374 \\
(6.97)\end{array}$ \\
\hline NASDAQ COMPOSI & $\begin{array}{c}0.011154 \\
(1.273)\end{array}$ & $\begin{array}{c}-0.004653 \\
(-0.6173)\end{array}$ & $\begin{array}{c}0.934643 \\
(87.21)\end{array}$ & $\begin{array}{c}0.123374 \\
(6.97)\end{array}$ \\
\hline NIKEY & $\begin{array}{c}0.003371 \\
(0.3792)\end{array}$ & $\begin{array}{c}0.041873 \\
(2.961)\end{array}$ & $\begin{array}{c}0.890520 \\
(69.10)\end{array}$ & $\begin{array}{c}0.090442 \\
(3.405)\end{array}$ \\
\hline PSI & $\begin{array}{c}0.023885 \\
(3.67)\end{array}$ & $\begin{array}{c}0.064853 \\
(4.4369)\end{array}$ & $\begin{array}{c}0.874999 \\
(43.87)\end{array}$ & $\begin{array}{c}0.099646 \\
(3.58)\end{array}$ \\
\hline SHCOMP & $\begin{array}{c}-0.000634 \\
(-0.0662)\end{array}$ & $\begin{array}{c}0.039487 \\
(3.958)\end{array}$ & $\begin{array}{c}0.931487 \\
(57.89)\end{array}$ & $\begin{array}{c}0.034109 \\
(2.137)\end{array}$ \\
\hline SHSZ300 & $\begin{array}{c}-0.003014 \\
(-0.2654)\end{array}$ & $\begin{array}{c}0.040297 \\
(3.849)\end{array}$ & $\begin{array}{c}0.932773 \\
(68.43)\end{array}$ & $\begin{array}{c}0.030505 \\
(1.169)\end{array}$ \\
\hline SPX & $\begin{array}{c}0.010721 \\
(1.9)\end{array}$ & $\begin{array}{c}-0.03043 \\
(-4.659)\end{array}$ & $\begin{array}{c}0.936503 \\
(89.07)\end{array}$ & $\begin{array}{c}0.164429 \\
(8.563)\end{array}$ \\
\hline SWISS & $\begin{array}{c}0.003919 \\
(0.6222)\end{array}$ & $\begin{array}{c}-0.006971 \\
(-0.8431)\end{array}$ & $\begin{array}{c}0.894692 \\
(76.33)\end{array}$ & $\begin{array}{c}0.177821 \\
(7.918)\end{array}$ \\
\hline SX5E & $\begin{array}{c}-0.006325 \\
(-0.8461)\end{array}$ & $\begin{array}{c}-0.028051 \\
(-4.536)\end{array}$ & $\begin{array}{c}0.926007 \\
(85.52)\end{array}$ & $\begin{array}{c}0.182252 \\
(7.915)\end{array}$ \\
\hline SZCOMP & $\begin{array}{l}0.000142 \\
(0.01338)\end{array}$ & $\begin{array}{c}0.04638 \\
(3.87)\end{array}$ & $\begin{array}{c}0.92931 \\
(56.94)\end{array}$ & $\begin{array}{c}0.02687 \\
(1.2)\end{array}$ \\
\hline
\end{tabular}

$t$-value is in parentheses.

The estimated persistence $(\alpha+\beta)$ is close to one in all cases but the process is stationary. This implies that when volatility is high in one period, it will be high in the 
next period too. However, some parameter constraints are not satisfied because the $\alpha$ parameter is negative in some cases.

As can be seen, the EGARCH $(1,1)$ model is able to detect the leverage effect in all cases except in three Asian indexes, HSI, SHSZ300 and SHCOMP because at a 5\% significance level, the $\gamma_{1}$ parameter is not statistically significant. In all cases, this parameter is negative, see Table 5 . This implies that negative returns exert a greater influence on volatility than positive returns.

Moreover, the highest values of the $\gamma_{1}$ parameter are for European and North American indexes while the lowest are for South American and Asian indexes. Persistence is high in all indexes which implies that if volatility is high in one period, it will be high in the next one too.

Table 5. Estimated results with an $\operatorname{EGARCH}(1,1)$

\begin{tabular}{|c|c|c|c|c|c|}
\hline \multicolumn{6}{|c|}{ EGARCH $(1,1)$ model estimation } \\
\hline Index & $\omega$ & $\alpha$ & $\beta$ & $\gamma_{1}$ & $\gamma_{2}$ \\
\hline AEX & $\begin{array}{r}-0.001938 \\
(0.04243)\end{array}$ & $\begin{array}{c}0.155572 \\
(0.6010)\end{array}$ & $\begin{array}{c}0.983547 \\
(152.5)\end{array}$ & $\begin{array}{c}-0.117460 \\
(-4.379)\end{array}$ & $\begin{array}{c}0.104292 \\
(5.254)\end{array}$ \\
\hline BOVESPA & $\begin{array}{c}0.007649 \\
(0.7826)\end{array}$ & $\begin{array}{c}-0.112593 \\
(-0.4034)\end{array}$ & $\begin{array}{c}0.979311 \\
(136.7)\end{array}$ & $\begin{array}{c}-0.08037 \\
(-2.737)\end{array}$ & $\begin{array}{c}0.123303 \\
(3.928\end{array}$ \\
\hline CAC & $\begin{array}{c}-0.005303 \\
(-0.7051)\end{array}$ & $\begin{array}{c}0.069989 \\
(0.3188)\end{array}$ & $\begin{array}{c}0.981121 \\
(266.4)\end{array}$ & $\begin{array}{c}-0.133063 \\
(-4.709)\end{array}$ & $\begin{array}{c}0.082381 \\
(5.267)\end{array}$ \\
\hline DAX & $\begin{array}{c}0.004613 \\
(0.7806)\end{array}$ & $\begin{array}{c}0.115249 \\
(0.4416)\end{array}$ & $\begin{array}{c}0.979534 \\
(222.7)\end{array}$ & $\begin{array}{c}-0.120695 \\
(-3.889)\end{array}$ & $\begin{array}{c}0.105957 \\
(5.552)\end{array}$ \\
\hline DJI & $\begin{array}{c}0.004613 \\
(0.7806)\end{array}$ & $\begin{array}{c}0.115249 \\
(0.4416)\end{array}$ & $\begin{array}{c}0.979534 \\
(222.7)\end{array}$ & $\begin{array}{c}-0.120695 \\
(-3.889)\end{array}$ & $\begin{array}{c}0.105957 \\
(5.552)\end{array}$ \\
\hline FTSE & $\begin{array}{c}-0.001851 \\
(-0.2911)\end{array}$ & $\begin{array}{c}0.032979 \\
(0.1707)\end{array}$ & $\begin{array}{c}0.981952 \\
(274.1)\end{array}$ & $\begin{array}{c}-0.118547 \\
(-5.197)\end{array}$ & $\begin{array}{c}0.11675 \\
(5.837)\end{array}$ \\
\hline HSI & $\begin{array}{c}0.008051 \\
(0.984)\end{array}$ & $\begin{array}{c}1.667539 \\
(0.6962)\end{array}$ & $\begin{array}{c}0.986059 \\
(343.3)\end{array}$ & $\begin{array}{c}-0.020675 \\
(-0.9584)\end{array}$ & $\begin{array}{c}0.046218 \\
(1.163)\end{array}$ \\
\hline IBEX & $\begin{array}{c}0.006591 \\
(0.864)\end{array}$ & $\begin{array}{c}-0.170824 \\
(-1.045)\end{array}$ & $\begin{array}{c}0.951928 \\
(252.8)\end{array}$ & $\begin{array}{c}-0.136076 \\
(-5.173)\end{array}$ & $\begin{array}{c}0.123592 \\
(6.01)\end{array}$ \\
\hline MERVAL & $\begin{array}{c}0.034089 \\
(2.533)\end{array}$ & $\begin{array}{c}0.429576 \\
(0.9482)\end{array}$ & $\begin{array}{c}0.965454 \\
(91.35)\end{array}$ & $\begin{array}{c}-0.029656 \\
(-2.141)\end{array}$ & $\begin{array}{c}0.126275 \\
(2.915)\end{array}$ \\
\hline MIB 30 & $\begin{array}{c}-0.004167 \\
(-0.5524)\end{array}$ & $\begin{array}{l}0.011021 \\
(0.04121)\end{array}$ & $\begin{array}{c}0.984159 \\
(266.6)\end{array}$ & $\begin{array}{c}-0.106265 \\
(-3.54)\end{array}$ & $\begin{array}{c}0.117308 \\
(4.853)\end{array}$ \\
\hline NASDAQ100 & $\begin{array}{c}0.010661 \\
(1.219)\end{array}$ & $\begin{array}{c}0.091305 \\
(0.3105)\end{array}$ & $\begin{array}{c}0.988192 \\
(359.4)\end{array}$ & $\begin{array}{c}-0.090023 \\
(-3.414)\end{array}$ & $\begin{array}{c}0.100882 \\
(5.018)\end{array}$ \\
\hline NASDAQ COMPOSI & $\begin{array}{c}0.010661 \\
(1.219)\end{array}$ & $\begin{array}{c}0.091305 \\
(0.3105)\end{array}$ & $\begin{array}{c}0.988192 \\
(359.4)\end{array}$ & $\begin{array}{c}-0.090023 \\
(-3.414)\end{array}$ & $\begin{array}{c}0.100882 \\
(5.018)\end{array}$ \\
\hline NIKEY & $\begin{array}{c}0.002118 \\
(0.3228)\end{array}$ & $\begin{array}{c}0.481137 \\
(0.9587)\end{array}$ & $\begin{array}{c}0.966118 \\
(137.9)\end{array}$ & $\begin{array}{c}-0.053394 \\
(-2.148)\end{array}$ & $\begin{array}{c}0.126306 \\
(2.792)\end{array}$ \\
\hline PSI & $\begin{array}{c}0.022344 \\
(3.335)\end{array}$ & $\begin{array}{c}-0.244685 \\
(-1.576)\end{array}$ & $\begin{array}{c}0.974131 \\
(141.4)\end{array}$ & $\begin{array}{c}-0.102507 \\
(-3.613)\end{array}$ & $\begin{array}{c}0.273431 \\
(6.021)\end{array}$ \\
\hline SHCOMP & $\begin{array}{c}-0.006313 \\
(-0.5914)\end{array}$ & $\begin{array}{l}0.221327 \\
(-0.7971)\end{array}$ & $\begin{array}{c}0.989864 \\
(199.6)\end{array}$ & $\begin{array}{c}-0.02191 \\
(-1.923)\end{array}$ & $\begin{array}{c}0.138403 \\
(2.984)\end{array}$ \\
\hline
\end{tabular}




\begin{tabular}{|c|c|c|c|c|c|}
\hline SHSZ300 & $\begin{array}{c}-0.007631 \\
(-0.6734)\end{array}$ & $\begin{array}{c}0.272856 \\
(0.3723)\end{array}$ & $\begin{array}{c}0.989004 \\
(210.6)\end{array}$ & $\begin{array}{c}-0.011246 \\
(-1.134)\end{array}$ & $\begin{array}{c}0.091648 \\
(1.726)\end{array}$ \\
\hline SPX & $\begin{array}{l}0.00461 \\
(0.7615)\end{array}$ & $\begin{array}{l}-0.005269 \\
(-0.02272)\end{array}$ & $\begin{array}{c}0.981487 \\
(231.1)\end{array}$ & $\begin{array}{c}-0.136298 \\
(-4.147)\end{array}$ & $\begin{array}{c}0.097735 \\
(6.263)\end{array}$ \\
\hline SWISS & $\begin{array}{c}0.002372 \\
(0.4354)\end{array}$ & $\begin{array}{c}-0.000569 \\
(-0.0003639)\end{array}$ & $\begin{array}{c}0.973762 \\
(239.0)\end{array}$ & $\begin{array}{c}-0.139996 \\
(-5.744)\end{array}$ & $\begin{array}{c}0.139535 \\
(6.338)\end{array}$ \\
\hline SX5E & $\begin{array}{c}-0.007309 \\
(-1.055)\end{array}$ & $\begin{array}{c}-0.039928 \\
(-0.2294)\end{array}$ & $\begin{array}{c}0.981053 \\
(269.6)\end{array}$ & $\begin{array}{c}-0.155004 \\
(-5.183)\end{array}$ & $\begin{array}{c}0.093729 \\
(5.831)\end{array}$ \\
\hline SZCOMP & $\begin{array}{c}0.010185 \\
(0.8922)\end{array}$ & $\begin{array}{c}-0.466696 \\
(-3.304)\end{array}$ & $\begin{array}{c}0.989241 \\
(186.9)\end{array}$ & $\begin{array}{c}-0.037492 \\
(-2.211)\end{array}$ & $\begin{array}{c}0.101256 \\
(4.675)\end{array}$ \\
\hline
\end{tabular}

$t$-value is in parentheses.

Table 6. Estimated results with an $\operatorname{APARCH}(1,1)$

\begin{tabular}{|c|c|c|c|c|c|}
\hline \multicolumn{6}{|c|}{$\operatorname{APARCH}(1,1)$ model estimation } \\
\hline Index & $\alpha_{0}$ & $\alpha$ & $\beta$ & $\gamma$ & $\delta$ \\
\hline AEX & \multicolumn{5}{|c|}{ NO CONVERGENCE } \\
\hline BOVESPA & $\begin{array}{c}0.005479 \\
(0.4594)\end{array}$ & $\begin{array}{c}0.037435 \\
(1.653)\end{array}$ & $\begin{array}{c}0.923574 \\
(50.06)\end{array}$ & $\begin{array}{c}0.663258 \\
(1.454)\end{array}$ & $\begin{array}{r}1.97617 \\
(6.620)\end{array}$ \\
\hline CAC & \multicolumn{5}{|c|}{ NO CONVERGENCE } \\
\hline DAX & \multicolumn{5}{|c|}{ NO CONVERGENCE } \\
\hline DJI & \multicolumn{5}{|c|}{ NO CONVERGENCE } \\
\hline FTSE & \multicolumn{5}{|c|}{ NO CONVERGENCE } \\
\hline HSI & $\begin{array}{l}0.006712 \\
(0.8068)\end{array}$ & $\begin{array}{c}0.049557 \\
(4.539)\end{array}$ & $\begin{array}{c}0.938695 \\
(139.3)\end{array}$ & $\begin{array}{c}0.542516 \\
(4.358)\end{array}$ & $\begin{array}{c}1.578299 \\
(5.079)\end{array}$ \\
\hline IBEX & \multicolumn{5}{|c|}{ NO CONVERGE } \\
\hline MERVAL & $\begin{array}{c}0.032462 \\
(2.437)\end{array}$ & $\begin{array}{c}0.074736 \\
(4.422)\end{array}$ & $\begin{array}{c}0.869996 \\
(37.40)\end{array}$ & $\begin{array}{c}0.156024 \\
(2.705)\end{array}$ & $\begin{array}{c}2.437812 \\
(2.109)\end{array}$ \\
\hline MIB 30 & \multicolumn{5}{|c|}{ NO CONVERGENCE } \\
\hline NASDAQ100 & \multicolumn{5}{|c|}{ NO CONVERGENCE } \\
\hline NASDAQ COMPOSI & \multicolumn{5}{|c|}{ NO CONVERGENCE } \\
\hline NIKEY & $\begin{array}{c}0.001730 \\
(0.1841)\end{array}$ & $\begin{array}{c}0.086252 \\
(7.492)\end{array}$ & $\begin{array}{c}0.896127 \\
(68.36)\end{array}$ & $\begin{array}{c}0.348508 \\
(2.546)\end{array}$ & $\begin{array}{c}1.604921 \\
(6.39)\end{array}$ \\
\hline PSI & $\begin{array}{l}0.21218 \\
(3.369)\end{array}$ & $\begin{array}{c}0.115051 \\
(7.197)\end{array}$ & $\begin{array}{c}0.887445 \\
(54.47)\end{array}$ & $\begin{array}{c}0.358211 \\
(4.583)\end{array}$ & $\begin{array}{c}1.092244 \\
(5.89)\end{array}$ \\
\hline SHCOMP & $\begin{array}{c}-0.000313 \\
(-0.3191)\end{array}$ & $\begin{array}{c}0.05864 \\
(3.828) \\
\end{array}$ & $\begin{array}{c}0.933796 \\
(65.13)\end{array}$ & $\begin{array}{c}0.160835 \\
(2.726)\end{array}$ & $\begin{array}{c}1.799519 \\
(6.597) \\
\end{array}$ \\
\hline SHSZ300 & $\begin{array}{c}-0.003629 \\
(-0.3119)\end{array}$ & $\begin{array}{c}0.061099 \\
(5.05)\end{array}$ & $\begin{array}{c}0.935813 \\
(70.77)\end{array}$ & $\begin{array}{c}0.14339 \\
(2.222) \\
\end{array}$ & $\begin{array}{c}1.638310 \\
(6.728)\end{array}$ \\
\hline SPX & \multicolumn{5}{|c|}{ NO CONVERGENCE } \\
\hline SWISS & \multicolumn{5}{|c|}{ NO CONVERGENCE } \\
\hline SX5E & \multicolumn{5}{|c|}{ NO CONVERGENCE } \\
\hline SZCOMP & $\begin{array}{l}0.000161 \\
(0.01444)\end{array}$ & $\begin{array}{c}0.062489 \\
(3.733)\end{array}$ & $\begin{array}{c}0.930725 \\
(61.33)\end{array}$ & $\begin{array}{c}0.122419 \\
(2.155)\end{array}$ & $\begin{array}{c}1.81795 \\
(6.595)\end{array}$ \\
\hline
\end{tabular}

$t$-value is in parentheses.

As can be seen in Table 6, the estimation of the APARCH $(1,1)$ model shows no converge in the estimation of the following twelve indexes: AEX, CAC, DAX, DJI, FTSE, IBEX, MIB 30, NASDAQ 100, NASDAQ COMPOSITE, SPX, SWISS and SX5E. In the remaining indexes, the leverage effect exits except in the BOVESPA index because at 
a $5 \%$ significance level, the $\gamma$ parameter is not statistically significant. In all cases, this parameter is positive. This implies that negative returns exert a greater influence on volatility than positive ones. The HSI has the highest value of the $\gamma$ parameter. The persistence is high in all indexes, which implies that when volatility is high in one period, it will be high in the next one.Finally, when we analyse the result obtained with the TA-ARSV, we see that this model detects the leverage effect in more cases than the asymmetric GARCH models and this is because the likelihood ratio contrast rejects the null hypothesis, see Table 7.

Table 7. The estimated results with TA-ARSV and ARSV

\begin{tabular}{|c|c|c|c|c|c|c|c|}
\hline & \multirow{2}{*}{\multicolumn{3}{|c|}{ TA-ARSV }} & \multirow{2}{*}{\multicolumn{2}{|c|}{ ARSV }} & & \\
\hline & & & & & & & \\
\hline & \multicolumn{3}{|c|}{ Estimated parameters } & \multicolumn{2}{|c|}{ Estimated parameters } & \multirow[b]{2}{*}{$\lambda$} & \multirow[b]{2}{*}{ Leverage effect } \\
\hline & $\sigma_{\star}$ & $\phi_{11}$ & $\phi_{12}$ & $\sigma_{*}$ & $\phi$ & & \\
\hline AEX & $\begin{array}{c}0.23267 \\
(0.114)\end{array}$ & $\begin{array}{l}0.98862 \\
(0.0814) \\
\end{array}$ & $\begin{array}{l}0.98967 \\
(0.0280)\end{array}$ & $\begin{array}{l}0.0308 \\
(0.125) \\
\end{array}$ & $\begin{array}{l}0.99947 \\
(0.1245)\end{array}$ & 13.76 & Yes \\
\hline BOVESPA & $\begin{array}{c}0.4713 \\
(0.0528)\end{array}$ & $\begin{array}{l}0.95749 \\
(0.1616)\end{array}$ & $\begin{array}{l}0.99804 \\
(0.1529)\end{array}$ & $\begin{array}{l}0.01753 \\
(0.1069)\end{array}$ & $\begin{array}{l}0.97990 \\
(0.2333)\end{array}$ & 20.98 & Yes \\
\hline CAC & $\begin{array}{c}0.227 \\
(0.073)\end{array}$ & $\begin{array}{c}0.9701 \\
(0.460)\end{array}$ & $\begin{array}{l}0.9988 \\
(0.387)\end{array}$ & $\begin{array}{c}0.278 \\
(0.089)\end{array}$ & $\begin{array}{l}0.9866 \\
(0.263)\end{array}$ & 6.98 & Yes \\
\hline DAX & $\begin{array}{c}0.225 \\
(0.078)\end{array}$ & $\begin{array}{l}0.9737 \\
(0.056)\end{array}$ & $\begin{array}{l}0.9989 \\
(0.144)\end{array}$ & $\begin{array}{c}0.284 \\
(0.096)\end{array}$ & $\begin{array}{l}0.9878 \\
(0.262)\end{array}$ & 5.32 & Yes \\
\hline DJI & $\begin{array}{c}0.278 \\
(0.113) \\
\end{array}$ & $\begin{array}{c}0.9745 \\
(0.2767)\end{array}$ & $\begin{array}{c}0.998 \\
(0.080)\end{array}$ & $\begin{array}{c}0.165 \\
(0.096)\end{array}$ & $\begin{array}{l}0.9864 \\
(0.258)\end{array}$ & 4 & Yes \\
\hline FTSE & $\begin{array}{c}0.135 \\
(0.077) \\
\end{array}$ & $\begin{array}{l}0.9694 \\
(0.475)\end{array}$ & $\begin{array}{c}0.999 \\
(0.632)\end{array}$ & $\begin{array}{c}0.179 \\
(0.095)\end{array}$ & $\begin{array}{c}0.986 \\
(0.266)\end{array}$ & 7.66 & Yes \\
\hline HSI & $\begin{array}{c}0.560 \\
(0.140)\end{array}$ & $\begin{array}{c}0.985 \\
(0.563)\end{array}$ & $\begin{array}{c}0.994 \\
(0.413)\end{array}$ & $\begin{array}{c}0.292 \\
(0.108)\end{array}$ & $\begin{array}{c}0.991 \\
(0.487)\end{array}$ & 7.55 & Yes \\
\hline IBEX & $\begin{array}{c}0.323 \\
(0.114)\end{array}$ & $\begin{array}{c}0.98646 \\
(0.132)\end{array}$ & $\begin{array}{l}0.9885 \\
(0.109)\end{array}$ & $\begin{array}{c}0.284 \\
(0.090)\end{array}$ & $\begin{array}{c}0.986 \\
(0.238)\end{array}$ & 5.6 & Yes \\
\hline MERVAL & $\begin{array}{c}0.037 \\
(0.194)\end{array}$ & $\begin{array}{c}0.937 \\
(0.933)\end{array}$ & $\begin{array}{c}0.988 \\
(0.364)\end{array}$ & $\begin{array}{c}0.033 \\
(0.172)\end{array}$ & $\begin{array}{c}0.960 \\
(0.217)\end{array}$ & 5.6 & Yes \\
\hline MIB 30 & $\begin{array}{c}0.185 \\
(0.094)\end{array}$ & $\begin{array}{c}0.976 \\
(0.6387)\end{array}$ & $\begin{array}{c}0.998 \\
(0.204)\end{array}$ & $\begin{array}{c}0.402 \\
(0.137)\end{array}$ & $\begin{array}{l}0.9882 \\
(0.287)\end{array}$ & 13.54 & Yes \\
\hline NASDAQ100 & $\begin{array}{c}2.56 \\
(0.246)\end{array}$ & $\begin{array}{c}0.98943 \\
(0.103)\end{array}$ & $\begin{array}{c}0.999 \\
(0.374)\end{array}$ & $\begin{array}{c}0.611 \\
(0.468)\end{array}$ & $\begin{array}{l}0.9983 \\
(0.416)\end{array}$ & 4.62 & Yes \\
\hline NASDAQ COMPOSI & $\begin{array}{c}0.981 \\
(0.162)\end{array}$ & $\begin{array}{l}0.9953 \\
(0.530)\end{array}$ & $\begin{array}{l}0.9979 \\
(0.535)\end{array}$ & $\begin{array}{c}0.341 \\
(0.140)\end{array}$ & $\begin{array}{c}0.993 \\
(0.363)\end{array}$ & 3.92 & Yes \\
\hline NIKEY & $\begin{array}{c}0.321 \\
(0.065)\end{array}$ & $\begin{array}{l}0.9779 \\
(0.094)\end{array}$ & $\begin{array}{l}0.9814 \\
(0.501)\end{array}$ & $\begin{array}{c}0.314 \\
(0.060)\end{array}$ & $\begin{array}{c}0.979 \\
(0.223)\end{array}$ & 4.42 & Yes \\
\hline PSI & $\begin{array}{c}0.142 \\
(0.184)\end{array}$ & $\begin{array}{c}0.979 \\
(0.6387)\end{array}$ & $\begin{array}{l}0.9199 \\
(0.142)\end{array}$ & $\begin{array}{l}0.596 \\
(1.22)\end{array}$ & $\begin{array}{c}0.999 \\
(0.117)\end{array}$ & 15.08 & Yes \\
\hline SHCOMP & $\begin{array}{c}0.27 \\
(0.047)\end{array}$ & $\begin{array}{l}0.9232 \\
(0.505) \\
\end{array}$ & $\begin{array}{c}0.951 \\
(0.524)\end{array}$ & $\begin{array}{c}0.285 \\
(0.059) \\
\end{array}$ & $\begin{array}{c}0.946 \\
(0.119)\end{array}$ & 4.04 & Yes \\
\hline SHSZ300 & $\begin{array}{c}0.358 \\
(0.053)\end{array}$ & $\begin{array}{l}0.9364 \\
(0.491) \\
\end{array}$ & $\begin{array}{c}0.991 \\
(0.829)\end{array}$ & $\begin{array}{c}0.402 \\
(0.137) \\
\end{array}$ & $\begin{array}{c}0.999 \\
(0.179)\end{array}$ & 35.4 & Yes \\
\hline SPX & $\begin{array}{c}0.185 \\
(0.094)\end{array}$ & $\begin{array}{c}0.987 \\
(0.675)\end{array}$ & $\begin{array}{c}0.998 \\
(0.632)\end{array}$ & $\begin{array}{c}0.402 \\
(0.137)\end{array}$ & $\begin{array}{c}0.993 \\
(0.392)\end{array}$ & 12.1 & Yes \\
\hline SWISS & $\begin{array}{c}0.119 \\
(0.068)\end{array}$ & $\begin{array}{c}0.956 \\
(0.346)\end{array}$ & $\begin{array}{c}0.999 \\
(0.362)\end{array}$ & $\begin{array}{c}0.166 \\
(0.064)\end{array}$ & $\begin{array}{c}0.979 \\
(0.183)\end{array}$ & 22.64 & Yes \\
\hline SX5E & $\begin{array}{c}0.272 \\
(0.086)\end{array}$ & $\begin{array}{c}0.971 \\
(0.630)\end{array}$ & $\begin{array}{c}0.989 \\
(0.655)\end{array}$ & $\begin{array}{c}0.279 \\
(0.089)\end{array}$ & $\begin{array}{c}0.986 \\
(0.253)\end{array}$ & 18.96 & Yes \\
\hline SZCOMP & $\begin{array}{c}0.352 \\
(0.062)\end{array}$ & $\begin{array}{c}0.968 \\
(0.557)\end{array}$ & $\begin{array}{c}0.974 \\
(0.116)\end{array}$ & $\begin{array}{c}0.367 \\
(0.055)\end{array}$ & $\begin{array}{c}0.962 \\
(0.442)\end{array}$ & 100.8 & Yes \\
\hline
\end{tabular}

'Likelihood Ratio Contrast ( $L R) . \lambda=-2\left(\operatorname{Ln} L^{R}-\operatorname{Ln} L\right)$. Critical value: $3.84(5 \%)$.

The value between parentheses for $\sigma^{*}, \phi_{11}, \phi_{12}$ and $\phi$ is the standard error. 
The $\phi_{12}$ parameter is greater than the $\phi_{11}$ parameter. This means that volatility is higher after negative returns than after positive ones. In each regime, persistence is measured with the $\phi_{11}$ and $\phi_{12}$ parameters. Both are always lower than one, which implies that the estimated process is stationary in all cases. The stationary problem can arise when using a model belonging to the asymmetric GARCH class, but this never occurs with a TA-ARV model. Moreover, the persistence is lower than the persistence estimated using other asymmetric GARCH models.

Volatility must be estimated properly and for this reason an appropriate model, such as TA-ARSV, should be used. Figure 6 shows the estimated volatility with different asymmetric models. In this case, we can observe that volatility varies from one model to the next. The AGARCH model shows the greatest difference in the estimations of volatility irrespective of the time. The estimations of volatility are more similar with the other asymmetric volatility models.

Moreover, we can overestimate or underestimate volatility depending on whether we are in a period of stability or instability, respectively. This might happen when we use an ARSV model, see figure 7 where the differences between ARSV and TA-ARSV model are calculated for FTSE, SPX and SHSZ300.

Figure 6. Estimated volatility with different Asymmetric Models for HSI index

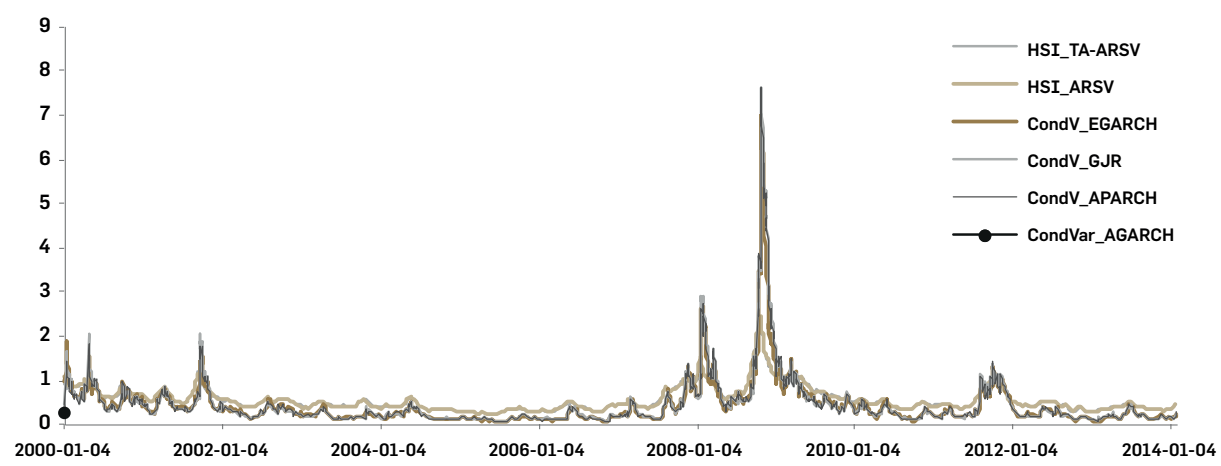

In the same way, we can say that the TA-ARSV(1) model provides better results than other models because the log-likelihood value is the best, see Table 8.

\section{Table 8. Log-likelihood estimated with different models}

\begin{tabular}{lc}
\hline Models & Log-likelihood \\
\hline EGARCH $(1,1)$ & -3010.47 \\
\hline GJR-GARCH $(1,1)$ & -3020.76 \\
\hline APARCH $(1,1)$ & -3016.55 \\
\hline AGARCH $(1,1)$ & -2310.53 \\
\hline ARSV $(1)$ & -2020.37 \\
\hline TA-ARSV $(1)$ & -2016.60 \\
\hline
\end{tabular}




\section{Concluding remarks}

An important variable in the behaviour of financial returns is volatility. Volatility is a measure of risk in the financial market and it is also non-observable. This paper focuses on two main points: firstly, a summary is provided of all the available statistical information about financial returns of different indexes in the world, together with the stylized facts, through statistical measures and econometric models; secondly, this prior information is used to determine which is the best model to explain the dynamics of volatility. To this end, we have used the ARSV and five asymmetric models: the AGARCH, the GJR-GARCH, the EGARCH, the APARCH and the TA-ARSV. These models allow us to obtain estimations of volatility and some of its stylized facts over the sample period, such as the leverage effect and the persistence in volatility for 20 indexes in the most important markets in the world.

The leverage effect exists in all analysed indexes according to the results obtained using the TA-ARSV(1) model. The AGARCH, EGARCH GJR-GARCH are not able to detect the asymmetric behaviour in the SHSZ300 and SZCOMP indexes and the EGARCH model fails to detect it in the HSI index. The APARCH model does not compute estimations for 12 indexes (American and European - except PSI). For these reasons, the TA-ARSV model is an effective model for estimating the leverage effect in different indexes around the world since it detects this stylized fact in more cases than the majority of the asymmetric GARCH models.

If the leverage effect exists, then volatility will be higher in the negative returns than in the positive ones. Moreover, TA-ARSV, EGARCH and GJR GARCH models show that the estimated asymmetric parameter is lower in the South American and Asian indexes than in the American and European ones for the analysed sample period.

On the other hand, all the models identify persistence in volatility for the analysed indexes. In most cases, this persistence is caused by volatility clustering. Furthermore, in all indexes analysed, the models estimated are stationary in covariance. The stationary problem can, however, sometimes arise when using a model belonging to the asymmetric GARCH class, something that never occurs with a TA-ARSV model.

Furthermore, the estimated volatility is higher (in the same cases) for the asymmetric GARCH models than for the TA-ARSV model, because the former are more sensitive to the outliers and might overestimate the volatility. However, the asymmetric GARCH models and the symmetric volatility models are, to date, the most commonly used in the stochastic volatility literature. For this reason, it is essential that volatility is properly estimated using a model such as TA-ARSV, because otherwise we may over- or underestimate market risk. 


\section{References}

Andersen, T.G., Bollerslev, T., Diebold, F.X. and Labys, P. (2003). Modeling and forecasting realized volatility, Econometrica, 71(2), pp. 579-625.

Black, F. (1976). Studies of stock price volatility changes. In proceedings from the American Statistical Association, Business and Economic Statistics section, pp 171-181.

Bollerslev, T. (1986). Generalized autoregressive conditional heteroskedasticity, Journal of Econometrics, $\mathbf{3 1}$, pp. 307-327.

Cont, R. (2001). Empirical properties of asset returns: Stylised facts and statistical issues. Quantitative Finance, 1, pp. 223-237.

Durbin, J.A. and Koopman, K.J. (1997). Monte carlo maximum likelihood estimation for non gaussian state space models. Biometrica, 84, pp.669-684.

Engle, R.F. (1982). Autoregressive conditional heteroscedasticity with estimates of the variance of UK inflation. Econometrica, 50, pp. 987-1007.

Engle, R.F. and Rothschild, M. (1990). Asset Pricing with Factor ARCH Covariance Structure: empirical Estimates for Treasure Bills, Journal of Econometrics, 45(1-2), pp. 213-238.

Ding, Z., Engle, R.R. and Granger, C.W.J. (1993). A long memory property of stock market returns and a new model, Journal of Empirical Finance, 1, pp. 83-106.

Durbin, J. and Koopman, S.J. (1997). Monte Carlo Maximum Likelihood Estimation for Non Gaussian State Space Models, Biometrica, 84, pp. 669-684.

García, M.C. and Mínguez, R. (2009). Estimation of Asymmetric Stochastic Volatility Models for Stock-Exchange Index Returns, International Advances in Economic Research, 15, pp. 71-87.

Glosten, L., Jagannaathan, R. and Runkle, D. (1993). The relation between the expected value and the volatility of the nominal excess return on stocks, Journal of Finance, 48, pp. 1779-1801.

Granger, C.W.J. and Ding, Z. (1995). Some properties of absolute returns: An alternative measure of risk, Annales d'Economie et de Statistique, 40, pp. 67-91.

Granger, C.W.J., Spear, S., and Ding, Z. (2000). Stylized facts on the temporal and distributional properties of absolute returns: An update, pp. 97-120. In Statistics and Finance: An Interface. In Chan, W-S, Li, W. K. and Tong (eds). Imperial college Press, London.

Harvey, A.C and Shephard, N. (1996). Estimation of an Asymmetric Stochastic Volatility Model for Asset Returns, Journal of Business and Economic Statistic, 14, pp. 429-434.

He, C. and Teräsvirta, T. (1999). Properties of the autocorrelation function of squared observations for second order GARCH process under two sets of parameter constraints, Journal of Times Series Analysis, 20, pp. 23-30.

Kim, T.H. and White, H. (2004). On more robust estimation of skewness and kurtosis, Finance Research Letters, 1, pp. 56-73.

- Malmsten, H. and Teräsvirta, T. (2004). Stylized facts of financial series and three popular models of volatility, Sse/efi working papers series in economics and finance, 563, Stockholm School of Economics. 
Montero, J.M, Fernández-Avilés, G. and García, M.C. (2011). A Threshold Autoregressive Stochastic Volatility Strategy to alert of Violations of the Air Quality Standards, International Journal Environment Research, 5(1), pp 23-32.

Nelson, N.B (1991). Conditional heteroscedasticity in returns: a new approach, Econometrica, 59, pp. 347-370.

Sandmann, G. and Koopman, S.J. (1998). Estimation of stochastic volatility models via Monte Carlo maximum likelihood, Journal of Econometrics, 87(2), pp. 271-301.

So, M.K.J., Li., W.K. and Lam, K. (2002). A threshold stochastic volatility model, Journal of forecasting, 21, pp. 473-500.

- Takayasu, M., T. and Takayasu, H. (2006). Potential force observed in market dynamics, Physica A, 370, pp. 91-115.

Taylor, S.J. (1986). Modeling Financial Time Series, John Wiley and Sons, Ltd, New York.

Teräsvirta, T. and Zhao, Z. (2007). Stylized facts of return series, robust estimates and three popular models of volatility. Working paper, Stockholm School of Economics.

Zakoïan, J.M. (1994). Threshold heteroscedastic models, Journal of Economic Dynamic and Control, 18, pp. 931-955. 